\title{
PUBLIC ADMINISTRATION AND LEGAL REGULATION EFFECTIVENESS IN THE FIELD OF HEALTH CARE IN THE CONTEXT OF SUSTAINABLE DEVELOPMENT
}

\author{
Oleksii Hutsaliuk $^{1}$ \\ Oksana Storozhuk ${ }^{2}$ \\ Yaroslav Zhovnirchyk ${ }^{3}$ \\ Oleksiy Zaiarniuk ${ }^{4}$ \\ Dmytro Kartsyhin ${ }^{5}$
}

\begin{abstract}
The purpose of the article is the study of health capital as the basis for the formation of human capital. The authors consider health capital as a new factor in economic growth in modern conditions. It is concluded that there is a high risk of a shortage of health capital due to high mortality, low fertility, and low life expectancy. There is also a shortage of investment in health care. The regional features of the development of the health capital of Ukraine in
\end{abstract} modern conditions are analyzed. The existence of regional differences in the formation of health capital is proved. The inconsistency of regional and national interests regarding the strategy of state regional policy is revealed. It is concluded that regional priorities should be such as to save and increase the health capital of health. The results of an integrated assessment made it possible to form a ranking of regions by indicators of health capital. The approaches

\footnotetext{
${ }^{1}$ Phd (Economics), Associate Professor, Head of the Department of Management,PHEI «International European University»,Kyiv, Ukraine

${ }^{2} \mathrm{PhD}$ in Economics, Associate Professor, Associate Professor of the Department of Economics, Management and Commerce, Central Ukrainian National Technical University, Kropyvnytskyi, Ukraine.

${ }^{3}$ Doctor of Sciences in Public Administration, Associate Professor, Professor of the Department of Public Management and Administration of the National Aviation University. Email: ya. zhovnirchyk @ukr.net

${ }^{4} \mathrm{PhD}$ in Economics, Associate Professor, Associate Professor of the Department of Economics, Management and Commerce, Central Ukrainian National Technical University, Kropyvnytskyi, Ukraine

${ }^{5}$ Graduate student of the Department of Civil, Commercial and Environmental Law at the University of Customs and Finance
} 
proposed by the authors to ranking the regions make it possible to develop programs of priority measures to implement the strategic goal of healthcare. It is an increase in the quality and accessibility of medical care, drug provision, ensuring the sanitary and epidemiological safety of the country, and the prevention of infectious diseases among the population.

Keywords: human capital, health capital, regional development, health capital index.

\section{Introduction}

Current economic reforms in Ukraine show the importance of human capital as the most valuable resource and basis for the development of high-tech industries. Much research has been done on education capital asset as an important factor in the formation of human capital. However, health capital asset, as an integral and essential part of human capital, is another main focus for scientists. The formation and development of human health capital is a key priority in strategic development. It allows increasing the competitiveness of the economy in the globalized
600

environment (Gubanova et al., 2019; Koval, Mikhno, 2019; Koval, Mikhno, Hajduga, Gaska, 2019). Unfortunately, the existing health capital of the Ukrainian regions is rapidly devaluing, which is reflected in a high level of natural depopulation and the decrease in life expectancy. The armed conflict in eastern Ukraine and the temporary occupation of the Autonomous Republic of Crimea adds complexity to the situation in the country. The key to effective functioning of the Ukrainian society in general and modernization of the regional economy is the sound management of regional socio-economic development including development of health capital asset.

\section{Literature review}

Theoretical basis of this work includes a significant contribution to the development of the provisions of the theory of human capital. Grossman (1972) proved the need for a demand model for health. Separated the concepts of human capital and health capital. Boarini, Mira d'Ercole, Liu (2012) are studied the phenomenon of eliminating diseases and epidemics on the general health of the population. Lorentzen, 
McMillan, Wacziarg (2008) studied the impact of health and mortality on economic growth. Grishnova, Brintseva (2015) is studied to the issues of human capital, including formation in the sphere of health. Koval, Popova etc. (2019) devoted her scientific articles to the problems of human development, ecodiagnostic and health (Koval et al., 2019b).

The studies are characterized the content of the economic category "human capital", analyzed its structure and condition, and identified its role, in particular, health as the most important indicator of the quality of human development. The scientists developed detailed recommendations for the development of health care system of Ukraine, improving demographic situation and social policy of the country.

\section{Materials and methods}

The authors propose medic approaches to the analysis of regional differences in the capital of public health. The authors use an integrated indicator, the index of development of health capital. It includes demographic, economic, social, environmental, territorial components and tourism
601

(Koval et al., 2019a). The calculation is based on official data of the State Statistics Committee of Ukraine. A special element of the methodological approach is the formation of a ranking of regions, which reflects the asymmetry of the development of capital of public health. The results of this ranking are the basis for the development of programs for the implementation of the health care reform strategy, taking into account regional characteristics.

The purpose of the article is to study health capital asset in the system of human capital; to find out the role of health capital in the transformation economy; to identify the factors that influence its formation and development, and to assess health capital of Ukraine in the regional context.

\section{Results}

Starting from the 1990s, Ukraine gradually moves towards building an innovative economy, the key resource of which is intelligence, knowledge, skills, competences, creativity, that is, human capital. The formation of human capital is driven by investment (Bodnar, Mirkovich, Koval, 2019). Investment in education and 
health are of utmost importance (Kvitka et al., 2019). Thus, there are two main components in human capital: education and health.

In our opinion, health capital is the basis for the formation and development of human capital. Without taking care of health, one cannot realize his or her potential in economic and other spheres of human activity (Fender, 2013).

The concept of "health capital" has not been fully studied in the Ukrainian economic literature. Basically, scientists view it as a component of human capital. However, according to the American economist and scientist Michael Grossman, health capital and human capital should be considered separately, because the skills to earn more and the opportunity to use these skills over time are different things. The amount of knowledge an individual possesses influences his or her performance, while the individual's health determines the total amount of time he or she can spend to earn income. This reserve is the capital of health (Grossman, 1972).

By health capital, we mean the investment in a person. The investment is needed to support and improve his/her health, performance, mobility and productivity. At the same time, health is both a consumer demand and an investment asset through which a person earns income. Investing in health capital involves costs on disease prevention, health care, dietary nutrition, and improved living conditions.

On the one hand, increasing life expectancy means extending the period of active work during which a person earns income and invests in his capital. On the other hand, public health losses, which are expressed in terms of morbidity, disability, and mortality, lead to significant economic losses.

In Ukraine, the health care system is seen as a cost sector that creates a burden on the budget and is generally loss-making for the country, as it does not produce products and is funded mainly at the expense of the state budget. Dynamics of the expenditures level of the consolidated budget of Ukraine on health care (in\% of GDP) in the period of 2013-2018 is characterized by the tendency to decrease from 4.2 to $3.26 \%$, which shows the passivity of the state in stimulating development of health capital. Instead, in the sphere of 
health insurance during 2013-2018 there was an increase in the amount of net insurance premiums for health insurance (continuous health insurance) and for insurance of medical expenses from 1.72 to 4.34 billion $\mathrm{UAH}$, that is by 2.5 times (Fig. 1). This indicates an increase of the
Ukrainians in the trust in insurance companies and understanding of the importance of investing in health capital. At the same time, it should be noted that health insurance in Ukraine is now in its development stage, so its impact on healthcare financing is insignificant.

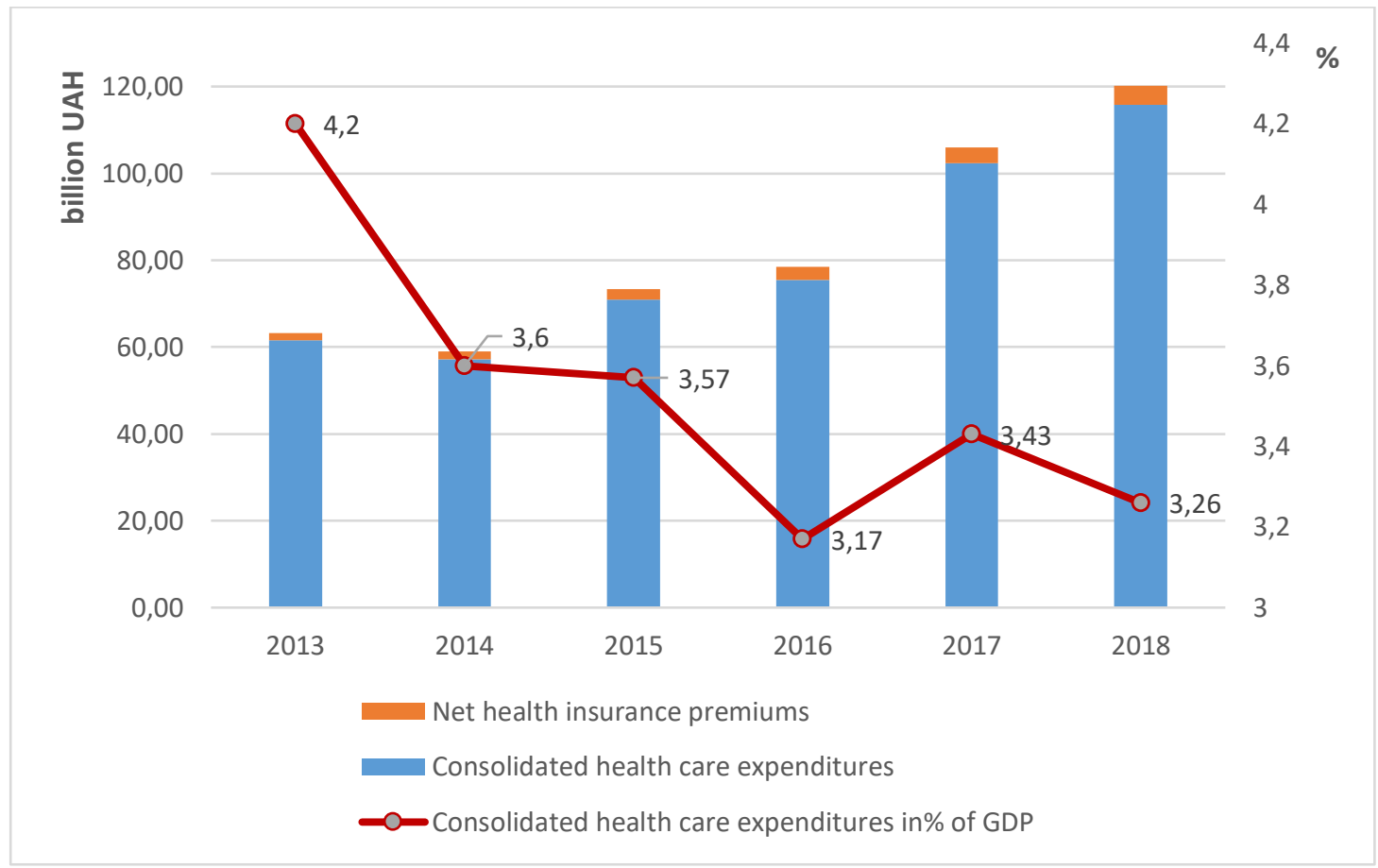

Fig. 1. Dynamics of budget expenditures on health care and net premiums from health insurance services in Ukraine (2013-2018).

Obviously, there is a problem of capital accumulation in Ukraine, and an increase in health care costs is necessary to accelerate economic growth.

This conclusion is particularly confirmed by the dynamics of Ukraine's rating positions among other countries of the world, which shows a downward nature. So, in the world prosperity index2019 Ukraine took 96th place out of 167 (Prosperity Rating, 2019). Experts emphasize that education and living conditions remain strong in Ukraine, but human capital, security and social 
protection (Borychenko et al., 2019), public administration (Bukanov et al., 2019) and state healthcare are weak.

Therefore, it is fair to point out that the reforms carried out by the government of our country, particularly in the medical sphere, do not lead to improvement of life of citizens. Although life expectancy in Ukraine has increased somewhat over the last ten years, it is still the lowest in Europe (for comparison: the average life expectancy at birth in 2017 in Ukraine was 72 years; in the EU countries - 81.3) (State Statistics Service of Ukraine, 2019).

In the meantime, investing in health provides a regular flow of workforce in production. Bad health, morbidity and disability lead to work incapacity. The lower the number of illnesses, the higher the level of health of the population and the return on investment in health care. Health capital formation encompasses not only macrobut also meso-, microeconomic levels as well as individual level. In our view, it is precisely the regional factor that is of great importance for Ukraine in view of the significant asymmetry in the level of social and economic development. Health capital is the source for the formation of human capital at mesoeconomic level. It stimulates social and economic development and innovation activity in the region and, therefore, increases its competitiveness and investment attractiveness (Koval, Slobodianiuk, Yankovyi, 2018). At the same time, health of population is shaped by the socio-economic, environmental, natural and climatic conditions of the region, which explains the need to study the specific characteristics of the territories concerning health capital.

While considering and assessing the differences in the state of health capital of the population of the regions of Ukraine, we form a set of indicators that, in our opinion, directly influence the formation and development of health capital. The indicators include: population morbidity, disability, mortality, birth rate, average life expectancy, household expenditures on health care, the level of environmental pollution in the region (Table 1). 


\begin{tabular}{|l|l|l|}
\hline \multicolumn{2}{|c|}{ Indicators } & \multicolumn{1}{c|}{ Indicator performance } \\
\hline K1 & Population morbidity & $\begin{array}{l}\text { Number of first reported cases of illness per 100,000 } \\
\text { population of the region }\end{array}$ \\
\hline K2 & Disability & $\begin{array}{l}\text { The ratio of the number of people with disabilities to the } \\
\text { residential population of the region }\end{array}$ \\
\hline K3 & Birth rate & Total birth rate \\
\hline K4 & Mortality & Total mortality rate \\
\hline K5 & Life expectancy & Average life expectancy at birth, years \\
\hline K6 & Health care costs & $\begin{array}{l}\text { The share of household expenditures on health care in the } \\
\text { structure of total household expenditures, \% }\end{array}$ \\
\hline K7 & $\begin{array}{l}\text { Environmental } \\
\text { pollution }\end{array}$ & Emissions of pollutants into the air, $\mathrm{t} / \mathrm{km}^{2}$ \\
\hline
\end{tabular}

Compiled by the authors

As there is no comprehensive scale of benchmark values of health capital indicators today, in order to ensure comparability and the ability to aggregate health capital development indicators, we will normalize them using the linear scaling method. The calculation of stimulus indicators (growth of which has a positive impact on health capital: birth rate, life expectancy at birth, household expenditures on health care) will be computed with the formula:

$$
N_{s k_{i}}=\frac{\text { factual value } k_{i}-\text { minimumvalue } k_{i}}{\text { maximumvalue } k_{i}-\text { minimum value } k_{i}}
$$

where $k_{i}$ is a partial indicator of the development of health capital of a region; $N_{s k i}$ is a standardized indicator of health capital development in a region. 


$$
N_{d k_{i}}=\frac{\text { maximumvalue } k_{i}-\text { factual value } k_{i}}{\text { maximum value } k_{i}-\text { minimumvalue } k_{i}}
$$

Calculation of the integral

index of health capital development on

the basis of standardized values of

partial indexes assumes weighting of

each indicator which has been included

in the sample. We will proceed under the principle of equal priority of all indicators selected for the calculation and compute Health Capital Index (HCI) as the arithmetic mean of partial indices:

$$
H C I=\frac{1}{7} \times\left(\sum N k_{i}\right),
$$

The results of calculations of the integral indicators of health capital of Ukraine in the regions are shown in Table 2.

\begin{tabular}{|c|c|c|c|c|c|c|c|c|c|}
\hline Region & K1 & $\mathrm{K} 2$ & K3 & K4 & K5 & K6 & K7 & $\mathrm{HCI}$ & $\begin{array}{c}\text { Ran } \\
\mathrm{k}\end{array}$ \\
\hline Vinnytsia & 0,672 & $\begin{array}{r}0,486 \\
1\end{array}$ & $\begin{array}{r}0,301 \\
9\end{array}$ & $\begin{array}{r}0,444 \\
4\end{array}$ & $\begin{array}{r}0,664 \\
1\end{array}$ & $\begin{array}{r}0,470 \\
6\end{array}$ & 0,902 & $\begin{array}{r}0,5630 \\
1\end{array}$ & 12 \\
\hline Volyn & $\begin{array}{r}0,570 \\
7\end{array}$ & $\begin{array}{r}0,486 \\
1\end{array}$ & $\begin{array}{r}0,830 \\
2\end{array}$ & $\begin{array}{r}0,728 \\
4\end{array}$ & $\begin{array}{r}0,358 \\
8\end{array}$ & $\begin{array}{r}0,147 \\
1\end{array}$ & 1 & $\begin{array}{r}0,5887 \\
5\end{array}$ & 8 \\
\hline $\begin{array}{l}\text { Dnepropetro } \\
\text { vsk }\end{array}$ & 0 & $\begin{array}{r}0,932 \\
1\end{array}$ & $\begin{array}{r}0,245 \\
3\end{array}$ & $\begin{array}{r}0,345 \\
7\end{array}$ & $\begin{array}{r}0,096 \\
7\end{array}$ & $\begin{array}{r}0,411 \\
8\end{array}$ & $\begin{array}{r}0,455 \\
3\end{array}$ & $\begin{array}{r}0,3552 \\
7\end{array}$ & 23 \\
\hline Zhytomyr & 0,697 & $\begin{array}{r}0,311 \\
8\end{array}$ & $\begin{array}{r}0,415 \\
1\end{array}$ & 0,321 & 0 & 1 & $\begin{array}{r}0,997 \\
1\end{array}$ & $\begin{array}{r}0,5345 \\
7\end{array}$ & 15 \\
\hline Zakarpattia & $\begin{array}{r}0,838 \\
8\end{array}$ & $\begin{array}{r}0,825 \\
8\end{array}$ & $\begin{array}{r}0,849 \\
1\end{array}$ & $\begin{array}{r}0,851 \\
9\end{array}$ & $\begin{array}{r}0,231 \\
6\end{array}$ & 0 & 1 & $\begin{array}{r}0,6567 \\
4\end{array}$ & 4 \\
\hline Zaporizhia & $\begin{array}{r}0,846 \\
6\end{array}$ & $\begin{array}{r}0,773 \\
5\end{array}$ & $\begin{array}{r}0,169 \\
8\end{array}$ & $\begin{array}{r}0,345 \\
7\end{array}$ & $\begin{array}{r}0,262 \\
1\end{array}$ & $\begin{array}{r}0,882 \\
4\end{array}$ & $\begin{array}{r}0,824 \\
2\end{array}$ & $\begin{array}{r}0,5863 \\
2\end{array}$ & 9 \\
\hline
\end{tabular}

Table 2. Grouping regions of Ukraine by health capital indicators 
Periódico do Núcleo de Estudos e Pesquisas sobre Gênero e Direito

Centro de Ciências Jurídicas - Universidade Federal da Paraíba V. 9 - $\mathrm{N}^{\circ} 02$ - Ano 2020 ISSN | 2179-7137 | http://periodicos.ufpb.br/ojs2/index.php/ged/index

\begin{tabular}{|c|c|c|c|c|c|c|c|c|c|}
\hline $\begin{array}{l}\text { Ivano- } \\
\text { Frankivsk }\end{array}$ & $\begin{array}{r}0,120 \\
8\end{array}$ & $\begin{array}{r}0,545 \\
3\end{array}$ & $\begin{array}{r}0,509 \\
4\end{array}$ & $\begin{array}{r}0,790 \\
1\end{array}$ & $\begin{array}{r}0,913 \\
5\end{array}$ & 0,5 & $\begin{array}{r}0,550 \\
4\end{array}$ & $\begin{array}{r}0,5613 \\
5\end{array}$ & 13 \\
\hline Kyiv & $\begin{array}{r}0,325 \\
8\end{array}$ & $\begin{array}{r}0,639 \\
4\end{array}$ & $\begin{array}{r}0,415 \\
1\end{array}$ & $\begin{array}{r}0,345 \\
7\end{array}$ & 0,056 & $\begin{array}{r}0,617 \\
6\end{array}$ & $\begin{array}{r}0,925 \\
1\end{array}$ & $\begin{array}{r}0,4749 \\
5\end{array}$ & 20 \\
\hline Kirovohrad & $\begin{array}{r}0,698 \\
6\end{array}$ & $\begin{array}{r}0,766 \\
6\end{array}$ & $\begin{array}{r}0,169 \\
8\end{array}$ & $\begin{array}{r}0,345 \\
7\end{array}$ & $\begin{array}{r}0,190 \\
8\end{array}$ & 0,5 & $\begin{array}{r}0,994 \\
2\end{array}$ & $\begin{array}{r}0,5236 \\
7\end{array}$ & 16 \\
\hline Lviv & $\begin{array}{r}0,335 \\
6\end{array}$ & $\begin{array}{r}0,430 \\
3\end{array}$ & $\begin{array}{r}0,509 \\
4\end{array}$ & $\begin{array}{r}0,753 \\
1\end{array}$ & $\begin{array}{r}0,834 \\
6\end{array}$ & $\begin{array}{r}0,235 \\
3\end{array}$ & $\begin{array}{r}0,867 \\
4\end{array}$ & $\begin{array}{r}0,5665 \\
2\end{array}$ & 11 \\
\hline Mykolaiv & $\begin{array}{r}0,636 \\
2\end{array}$ & $\begin{array}{r}0,827 \\
5\end{array}$ & 0,283 & $\begin{array}{r}0,493 \\
8\end{array}$ & $\begin{array}{r}0,249 \\
4\end{array}$ & $\begin{array}{r}0,176 \\
5\end{array}$ & $\begin{array}{r}0,994 \\
2\end{array}$ & $\begin{array}{r}0,5229 \\
4\end{array}$ & 17 \\
\hline Odesa & $\begin{array}{r}0,577 \\
4\end{array}$ & $\begin{array}{r}0,714 \\
3\end{array}$ & $\begin{array}{r}0,603 \\
8\end{array}$ & $\begin{array}{r}0,617 \\
3\end{array}$ & 0,229 & $\begin{array}{r}0,088 \\
2\end{array}$ & $\begin{array}{r}0,976 \\
9\end{array}$ & $\begin{array}{r}0,5438 \\
4\end{array}$ & 14 \\
\hline Poltava & $\begin{array}{r}0,958 \\
2\end{array}$ & $\begin{array}{r}0,656 \\
8\end{array}$ & $\begin{array}{r}0,132 \\
1\end{array}$ & 0,284 & $\begin{array}{r}0,427 \\
5\end{array}$ & $\begin{array}{r}0,588 \\
2\end{array}$ & $\begin{array}{r}0,956 \\
8\end{array}$ & $\begin{array}{r}0,5719 \\
4\end{array}$ & 10 \\
\hline Rivne & $\begin{array}{r}0,383 \\
3\end{array}$ & 0,77 & $\begin{array}{r}0,943 \\
4\end{array}$ & $\begin{array}{r}0,814 \\
8\end{array}$ & 0,458 & $\begin{array}{r}0,411 \\
8\end{array}$ & $\begin{array}{r}0,994 \\
2\end{array}$ & $\begin{array}{r}0,6822 \\
1\end{array}$ & 3 \\
\hline Sumy & 1 & $\begin{array}{r}0,890 \\
2\end{array}$ & 0 & $\begin{array}{r}0,333 \\
3\end{array}$ & $\begin{array}{r}0,554 \\
7\end{array}$ & $\begin{array}{r}0,823 \\
5\end{array}$ & $\begin{array}{r}0,982 \\
7\end{array}$ & $\begin{array}{r}0,6549 \\
1\end{array}$ & 5 \\
\hline Ternopil & $\begin{array}{r}0,569 \\
3\end{array}$ & 0,716 & $\begin{array}{r}0,301 \\
9\end{array}$ & $\begin{array}{r}0,592 \\
6\end{array}$ & $\begin{array}{r}0,842 \\
2\end{array}$ & $\begin{array}{r}0,970 \\
6\end{array}$ & $\begin{array}{r}0,988 \\
5\end{array}$ & $\begin{array}{r}0,7115 \\
8\end{array}$ & 2 \\
\hline Kharkiv & $\begin{array}{r}0,630 \\
8\end{array}$ & $\begin{array}{r}0,806 \\
6\end{array}$ & $\begin{array}{r}0,150 \\
9\end{array}$ & $\begin{array}{r}0,395 \\
1\end{array}$ & $\begin{array}{r}0,335 \\
9\end{array}$ & $\begin{array}{r}0,264 \\
7\end{array}$ & $\begin{array}{r}0,968 \\
3\end{array}$ & $\begin{array}{r}0,5074 \\
7\end{array}$ & 18 \\
\hline Kherson & $\begin{array}{r}0,972 \\
5\end{array}$ & 1 & $\begin{array}{r}0,415 \\
1\end{array}$ & $\begin{array}{r}0,444 \\
4\end{array}$ & $\begin{array}{r}0,109 \\
4\end{array}$ & $\begin{array}{r}0,294 \\
1\end{array}$ & $\begin{array}{r}0,997 \\
1\end{array}$ & $\begin{array}{r}0,6046 \\
5\end{array}$ & 7 \\
\hline $\begin{array}{l}\text { Khmelnytsky } \\
\text { i }\end{array}$ & $\begin{array}{r}0,703 \\
7\end{array}$ & 0 & $\begin{array}{r}0,358 \\
5\end{array}$ & $\begin{array}{r}0,444 \\
4\end{array}$ & $\begin{array}{r}0,559 \\
8\end{array}$ & $\begin{array}{r}0,294 \\
1\end{array}$ & $\begin{array}{r}0,976 \\
9\end{array}$ & $\begin{array}{r}0,4767 \\
7\end{array}$ & 19 \\
\hline Cherkasy & $\begin{array}{r}0,670 \\
9\end{array}$ & $\begin{array}{r}0,142 \\
9\end{array}$ & $\begin{array}{r}0,113 \\
2\end{array}$ & $\begin{array}{r}0,308 \\
6\end{array}$ & $\begin{array}{r}0,432 \\
6\end{array}$ & $\begin{array}{r}0,411 \\
8\end{array}$ & 0,928 & $\begin{array}{r}0,4297 \\
2\end{array}$ & 21 \\
\hline Chernivtsi & $\begin{array}{r}0,713 \\
8\end{array}$ & $\begin{array}{r}0,804 \\
9\end{array}$ & $\begin{array}{r}0,584 \\
9\end{array}$ & $\begin{array}{r}0,827 \\
2\end{array}$ & $\begin{array}{r}0,954 \\
2\end{array}$ & $\begin{array}{r}0,529 \\
4\end{array}$ & 1 & $\begin{array}{r}0,7734 \\
8\end{array}$ & 1 \\
\hline
\end{tabular}




\begin{tabular}{|l|r|r|r|r|r|r|r|r|r|}
\hline Chernihiv & 0,456 & 0,489 & 0,056 & 0 & 0,109 & 0,411 & 0,982 & 0,3580 & 22 \\
& 6 & 5 & 6 & & 4 & 8 & 7 & 8 & \\
\hline Kyiv city & 0,091 & 0,916 & 1 & 1 & 1 & 0,294 & 0 & & 6 \\
& 7 & 4 & & & & 1 & & 0,6146 & \\
\hline
\end{tabular}

Excluding Donetsk and Luhansk regions

The data in Table 2 allow identifying the top three regions in terms of HCI. They are Chernivtsi, Ternopil and Rivne regions. They are characterized by low morbidity rates, high birth rates, high life expectancy rates, and low environmental pollution. The worst indicators of health capital are observed in Dnipropetrovsk, Chernihiv and Cherkasy regions. The regions outsiders are characterized by high morbidity rates, low birth rates and high mortality rates, especially in Chernihiv region. High level of environmental pollution is observed in Dnipropetrovsk and Cherkasy regions.

The data reveal some specific features regarding the state of health capital by regional differentiation.

Thus, we have considered health capital in the regions of Ukraine and determined that health is a significant element of human capital, since it depends directly on its level how well and fully a person can work, make income for himself and his family, the employer and the state. Therefore, healthcare costs are a profitable investment with a long-term and everincreasing return.

The ranking of the regions of Ukraine by major indicators of health capital confirms the asymmetry of the development of the health capital of the population in the regional context. For the industrial regions of Ukraine Dnipropetrovsk, Cherkasy, Kyiv, Kharkiv regions - health capital indicators have low values and identify adverse health status of the population.

Particularly difficult is the situation in Dnipropetrovsk, Chernihiv and Cherkasy regions. Here the high morbidity of the population, high mortality, low fertility.

The best indicators of health capital in the Western regions of Ukraine are Chernivtsi, Ternopil, Rivne. There is low morbidity, low pollution of territories, high life expectancy. 
The authors' ranking of the regions allows the development of programs of priority measures for the implementation of the strategy of development of capital of health of the population of Ukraine. The regional analysis has shown that measures to promote health capital development at the state level should be geared to the specificity of the regions regarding the formation and use of preconditions for the development of health capital.

The priority tasks for quality reproduction of capital of health of the population of Ukraine in general should be the following:

1. Increasing public funding for health care, in particular, to address the critical physical and moral deterioration of medical equipment and equipment available in our country's healthcare facilities. Thus, at the end of 2017 , the total wear and tear on fixed assets of medical institutions was $45.6 \%(55.1 \%$ overall in Ukraine). It is no secret that in hospitals there are often no necessary medicines, even for emergency medical care.

The problem of increased migration of health care workers, first of all, due to low wages (yes, wages in health care and social assistance at the end of 2019 amounted to UAH 8505, which is $69 \%$ ) from the average wage in the economy). Studies show that, after the reform, salaries have increased slightly from doctors and have remained at a minimal level for nurses. At the same time, the workload has increased several times, as most doctors do not own a computer and all the work on the maintenance of electronic declarations has to be done by junior medical staff.

It is the insufficiency of state funds allocated to the industry that causes a decrease in the volume of free medical services, "delaying" the overhaul of the facilities of medical establishments, equipment upgrades, and relatively low salaries of medical personnel.

2. Employing voluntary health insurance at the expense of the employer (today the Ukrainian health financing system can only attract $1 \%$ of households' expenditures in the form of voluntary risk insurance, and no more than $6 \%$ of Ukrainians cover personal insurance programs in Ukraine). In the meantime, health insurance has significant benefits for both the employer (reducing costs associated 
with disability of employees; maintaining the solvency of employees; improving the image of the manager in the team) and for the employee (access to quality health services at an affordable price with individual needs).

3. Active promotion of healthy lifestyles. Alcohol, drug and tobacco consumption should be combated, as an alternative is to show tobacco and antialcohol commercials. Such measures should increase the attractiveness of healthy lifestyles and explain to the population the link between today's investment in health capital and its future improvement. International experience shows that public health is significantly influenced by public policies aimed at shaping a healthy lifestyle strategy. Namely, the values and priorities associated with disease prevention, regular medical check-ups, a culture of good nutrition, and abandonment of bad habits.

4. The need to refine the concept of eHealth eHealth development in order to build an effective healthcare model in Ukraine through digital transformation.

The digital transformation of the healthcare system must be actively supported at the state level. Main directions of development of digital technologies in medicine: means of control of physiological parameters of the person; personalized approach in diagnostics; blockchain technologies for the development of preventive medicine. It is also important for the new model to function in parallel with the traditional one to minimize the risks of introducing new medical technologies and products.

It should be emphasized that the telemedicine system, as a field of new technologies, is widely used all over the world. Most often - in cardiology, ultrasound, mammology and surgery. The system gives you the opportunity to consult your doctor online for video and audio. And it helps to save not only time but also money: the cost of taking online is less expensive than an in-person consultation.

But along with the benefits, there are also some risks to the introduction of digital technology in medicine. For example, shared databases, accessible to large numbers of people, create the conditions for invasion of privacy. The authorities should convince patients that their data, including those relating to sensitive areas 
such as reproductive health, are securely protected. Therefore, it is necessary to train physicians in digital skills, including the ability to adapt to infrastructure instability. It is necessary to adopt a program that has clearly defined measures, timelines and executors. All this must be reflected in the regulatory field of our state.

\section{Conclusions}

In this study regional features were studied such parameters of human capital as: physical health of the population, investments in healthcare and the environment. Possibilities of practical application of the results of the proposed approach to the assessment of health capital lie in the orientation of social policy of the state to eliminate the effects of certain threats to the destruction of health capital in certain regions of the country.

Obviously, today there is a problem of low accumulation of health capital in Ukraine. The solution to this problem is to develop a well-thought-out long-term strategy to ensure high quality of life and health of the population of Ukraine and to apply it in practice. Today, unfortunately, there is no national strategy for human capital development in Ukraine. A key challenge for Ukraine in the sphere of health care is to create and develop a strategy, policy and regulatory framework in the sphere. All participants need to understand a strong industry building policy for investments and sustainable development. It is necessary to develop civil society institutions, which will ensure effective control of the society over the authorities.

\section{References}

Becker, G. (1975). Capital and the Personal Distribution of Income: An Analitical Approach. In: Human Capital. Chicago.

Boarini, R., Mira d'Ercole M., Liu, G. (2012). Approaches to Measuring the Stock of Human Capital: A Review of Country Practices. OECD Statistics Working Papers, No. 2012/04, OECD Publishing, Paris, https://doi.org/10.1787/5k8zlm5bc3nsen.

Bodnar, S., Mirkovich, I., Koval, V. (2019). Human capital development in Ukrainian education system by means of 
language integrated teaching. Dilemas contemporaneos-educacion politica y valores, 7 (SI), 14.

Borychenko, K., Hudz, A., Koval, V., Golubkova, I., Mazur, A. (2019). European standards for social protection of internally displaced persons. Dilemas contemporaneos-educacion politica $\mathrm{y}$ valores, 7 (SI), 88 .

Bukanov, H., Kolesnyk, A., Tashkinova, O., Kotlubai, V., Koval, V. (2019). Social marketing in public administration of social service institutions. Revista Genero \& Direito, 8 (6), 457-468.

Espreso (2019). Prosperity Rating: Ukraine ranked 96th among 167 countries. $\quad$ Retrieved from https://espreso.tv

Fender, V. (2013). Measuring the UK's Human Capital Stock. Methodology Guidance London, Office for National Statistics.

Fuchs, V. (1979). The Economic of Health in a Post - Industrial Society] The Public Interest.
Grishnova, O. A., Dorosh, O.V., Shurpa, S.E. (2015). Investing in human capital in a system of factors of decent work. Kyiv: KNEU.

Grishnova, O.A., Brintseva, O.G. (2015). Fictitious human capital: essence, characteristics, formation factors. Demografiya ta social'na ekonomika, 1 (23).

Grossman, M. (1972). The Demand for Healrh: A Theoretical and Empirical Investigation. N.Y.

Gubanova, E., Kupinets, L., Deforzh, H., Koval, V., Gaska, K. (2019). Recycling of polymer waste in the context of developing circular economy. Architecture Civil Engineering Environment, 12(4), 99-108. doi: 10.21307/ACEE-2019-055

Koval, V., Mikhno I. (2019). Ecological sustainability preservation of national economy by waste management methods. Economics. Ecology. Socium, 3(2), 30-40. 
Koval, V., Mikhno, I., Hajduga, G. \& Gaska, K. (2019). Economic efficiency of biogas generation from food product waste. E3S Web Conf. 100, 00039.

Koval, V., Mykhno, Y., Antonova, L., Plekhanov, D., \& Bondar, V. (2019a). Analysis of environmental factors' effect on the development of tourism. Journal of Geology, Geography and Geoecology, 28(3), 445-456.

https://doi.org/10.15421/111941

Koval, V., Petrashevska, A., Popova, O., Mikhno, I., \& Gaska, K. (2019b). Methodology of ecodiagnostics on the example of rural areas. Architecture Civil Engineering Environment, 12(1), 139-144. doi: 10.21307/ACEE-2019013

Koval, V., Slobodianiuk, O., \& Yankovyi, V. (2018). Production forecasting and evaluation of investments using Allen two-factor production function. Baltic Journal of Economic Studies, 4(1), 219-226. doi:10.30525/2256-0742/2018-4-1-219226
Kvitka, S., Starushenko, G., Koval, V., Deforzh, H., \& Prokopenko, O. (2019). Marketing of Ukrainian higher educational institutions representation based on modeling of Webometrics Ranking. Marketing and Management of Innovations, $\quad 3, \quad 60-72$. http://doi.org/10.21272/mmi.2019.3-05

State Statistics Service of Ukraine (2019). Ranking of regions Retrieved from: http://www.ukrstat.gov.ua[in Ukrainian]

World Bank (2005). Where is the Wealth of Nations? Measuring Capital for the 21st Century. Washington, DC 